This principle splits the magnetic guiding field into sectors that are alternately strongly focusing and defocusing. The net effect of a combination of sectors in this way is a strongly focusing action such that any oscillations about the equilibrium orbit induced in the motions of the particles are kept small in amplitude. This is of outstanding importance since, for a given energy, the particles may be constrained within an annulus of much smaller dimensions than is the case with a machine of conventional design. Preliminary study has suggested that it should be quite practical to design a machine for $30 \mathrm{GeV}$. in which the energy to be stored in the magnetic field is not more than that required for the present 3-GeV. machine at Brookhaven. The work of the Proton Synchrotron Group has been changed to take advantage of this new idea. The Council expressed its approval of this.

One part of the work of the Council's Group directed by Prof. Niels Bohr is to promote forms of European co-operation in nuclear physics other than the creation of the laboratory. Sweden has offered to the Council facilities on the $200-\mathrm{MeV}$. cyclotron which is now working at the University of Uppsala, and Prof. Bohr reported that he has arranged on the Council's behalf for two or three young nuclear physicists from other European countries to take part in work with the machine. Great Britain also has offered facilities on the $400-\mathrm{MeV}$. cyclotron now nearing completion at the University of Liverpool, and this, too, has been accepted. Prof. Bohr also described an experiment carried out at the Institute of Theoretical Physics, Copenhagen, by Prof. J. C. Jakobsen, which was of interest to the Council because it illustrated the new focusing principle proposed for proton synchrotrons. Four sections of a magnet were used, being constructed so as to provide focusing and defocusing fields in alternate sections. Particles were injected from an alpha-particle source into these fields, and it has been shown by the use of a photographic plate that they were brought to a focus at the end of the fourth section. This experiment has provided confirmation of the first-order theory of the new focusing method. While it was recognized that the experiment still left unanswered important questions about particle stability under practical operating conditions, the Council expressed its appreciation of the work.

In a report by Di. I. L. Kowarski, it was stated that the main work of the Laboratory Group since the Council's last meeting has been concerned with obtaining the relevant technical information about the sites offered for the laboratory and with the preparation of a draft convention for the building stage. Four member States had made formal applications to the Council to have the laboratory built in their territory, namely, France, Denmark, Holland and Switzerland; each country had supplied detailed information about its site and had been invited to make the case for it to the Council. From the information given, it appeared that any of the four sites would be satisfactory on purely technical grounds. It was generally recognized that the choice would also take into account other considerations, such as the balance between international common good, plus the national benefit from it, on one side, and the necessary sacrifice of national resources, on the other. Competition between each of the four member States to have the laboratory within its territory was keen, but the subject was debated in a courteous atmosphere, and when all but Switzerland had withdrawn their offers, however reluctantly Geneva was unanimously chosen as the site for the future laboratories.

Since the Council had decided at its second meeting to give support to cosmic-ray research, the secretarygeneral reported to it the results of an international expedition which had been independently organized and operated in the Mediterranean area to carry out research in the high atmosphere using balloons. A total of thirteen balloons has been launched, and 1,300 e.c. of emulsion exposed to radiation at $70,000 \mathrm{ft}$. for an average time of $6 \frac{1}{2}$ hours has been recovered. This is approximately ten times more emulsion than has previously been exposed. It was considered that, besides providing a considerable amount of material for research work, the expedition has been very useful for improving the technique of balloon launching.

In his draft of an interim report for the governments of member States, the secretary-general outlined how the Council came into being, its present stage of development and its plans for the future. At the present time studies concerning the equipment and organization of a laboratory are in full progress. It is hoped that by the spring of 1953 these studies will have advanced sufficiently to allow member States to take final decisions regarding the construction of an international nuclear research laboratory, and the organization of other forms of co-operation in nuclear research. It is estimated that the next stage of development will last seven years and cost a total of 27 million dollars, after which the estimated annual running cost of the laboratory would be a maximum of $1 \frac{1}{2}$ million dollars. Very preliminary consideration was given to questions of organization which will arise in the third stage and to the form of the convention which will set out the constitution of the organization. This report is to be studied again by the Council before it is submitted to the governments.

\section{TERCENTENARY OF THE LEOPOLDINA ACADEMY, SCHWEINFURT}

$T_{\mathrm{H}}^{\mathrm{H}}$

HE tercentenary of the foundation of the Leopoldina Academy in Schweinfurt, Bavaria, in the West Zone of Germany, was commemorated during July 13-15 under the auspices of the civic authorities and Historical Society of the town. This was in the nature of a Nachfeier to the main celebrations at Halle in the East Zone of Germany (see Nature, April 5, p. 576), at which the Schweinfurt delegate was Dr. Josef Helfrich. Prior to the zonal split, the late president of the Academy, Prof. Emil Abderhalden, who died in Zurich in 1950, had hoped for the tercentenary celebration to be held in Schweinfurt.

The Senate of the Academy at Halle, under its newly elected president, Prof. Otto Schlüter, and new senior vice-president, Prof. Heinrich Brandt, was represented by the secretary, Prof. Rudolph Zaunick, of Dresden (East Zone), who placed a wreath on the grave of the founder, Dr. Johann Lorenz Bausch (1605-65), reported on the present activity and projects of the Academy, and held a business meeting of members. The Martin-Luther University of Halle was represented by the rector, Prof. Rudolf Agricola. Prof. Michele Gortani brought greeting: 
from the University and Academy of Bologna. A telegram was read from the veteran member, (the late) Sven Hedin, the Swedish explorer.

Prof. Zaunick spoke at the opening session on "Idee, Form und Inhalt der Akademie in der Antike". He showed how the modern idea of a scientific

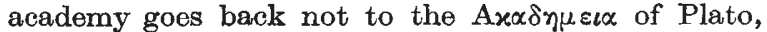
which excluded and explicitly ridiculed experimentation, but to Ptolemy's Movası v.

At the scientific session, Prof. Wilhelm Lorey, of Frankfurt, spoke on "Persönliche Erinnerungen an Mathematiker unter den einstigen Akademie-Mitglieder'. The Leopoldina Academy, which started as a medical society, took in no pure mathematicians as such until 1876. But some members, such as Werneburg, Goethe's contemporary, like him hostile to Newton's colour theory, and a fanatical protagonist of the duodecimal system, had started life as mathematicians, and many more, like Goethe, recognized the great educative value of mathematics. A pupil of Georg Cantor at Halle and of Felix Klein at Göttingen, Prof. Lorey recalled that he was often the sole audience at Cantor's lectures; and as one of the very few surviving contemporaries of Grace Chisholm (afterwards Mrs. W. H. Young) at Klein's seminar, he told the story behind her 'unforgettable' first appearance in the famous armchair at Klein's house. An enlightened Prussian Minister for Education, who thought mathematics the best subject to use as a guinea pig in testing whether women could or should be admitted to the universities, but wished to create no precedent for German women, entrusted to Klein the task of making suitable inquiries on his professional travels abroad. Grace Chisholm came from Cambridge and Mary Winston from the United States, and by their success opened up university careers to German women. The talk was illustrated by lantern-slide portraits of many eminent mathematicians whom the speaker had known personally.

Dr. Steck, of Nuremberg, under the title "Albrecht Dürer als Mathematiker und Kunsthistoriker", claimed that Dürer had made a thorough study of mathematics and expressed life-long ideas on the unity of beauty and truth in his last three written works, "Unterweisung der Messung . . ." (1525), "Befestigungslehre" (1527) and "Proportionslehre", published posthumously (1528).

Prof. Hans Gallwitz, director of the Geological Institute at Halle, gave a talk of the greatest interest on "Ausgrabungen von Wirbeltieren und Insekten in der Eozänen Braunkohle". Unique palæontological discoveries have been made in the open-cast coalmines in the Geiselthal near Halle. Excavations started by J. Weigelt in 1928 have only since the Second World War been successfully resumed, and praise is due to the mine-management and workers for their consistent co-operation. A film taken on the spot showed how specimens are detached and treated for preservation. The finds are unusually complete: not only whole skeletons, but also some skin, muscle and other soft-tissue remains are found, and even colours have been preserved in some green plant leaves and iridescent beetles. It is clear that the rate of sedimentation was rapid enough to prevent the attack of organic substances by atmospheric oxygen. Moreover, large desert tracts surrounded the district, isolating it and its inhabitants. The coal strata have an extensive surface area and attain a thickness of up to $100 \mathrm{~m}$. on the southern rim. Tectonic movements, and particularly subsidence due to salt-leaching in the underlying
Permian, can be clearly traced in the profiles; the formation of deep water-holes produced by the aforementioned process was particularly favourable to the concentration of specimens ; others are found closely scattered over certain areas, called Leichenfelder, which were subject to recurrent flooding and which must have been formed as the result of periodically recurrent catastrophes.

The period, about forty million years ago, to which the finds belong lies near the beginning of the massdevelopment of the mammalian order. Plant remains clearly indicate a tropical and sub-tropical climate, and a dual rainy season is evidenced both by the two-fold lamination in the coal profile and by the otoliths of fish. In fishes and frogs, the shape of cutaneous pigment-carriers as seen under the microscope points to asphyxiation. Minute specimens of insect larvæ, pollen grains of the order of $10^{-6} \mathrm{gm}$. in weight, and even bacteria in the tracheæ of insects have been discovered. Among the finds are giant serpents, long-legged alligators, crocodiles with partially incubated eggs, a mammal transitional between insectivores and prosimians (with both hairs and spines), and one of the early prototypes of the horse, one foot high, with three toes on the hind-feet and four on the fore-feet.

Prof. H. Burgeff, of Würzburg, fresh from a visit to the United States, spoke on "Samenkeimung, Entwicklung und Kultur deutscher Orchideen", elucidating by diagrams and lantern-slides his method of cultivation in a double flower-pot, the seeds being planted individually in a net or weft of fungus-threads. The method has succeeded for all indigenous orchids, after guarding against the danger of destruction by mice, whereas the usual method has always failed except for the Platanthera.

Several speakers, notably Prof. Hämel, of the two-hundred year old Bavarian Academy of Sciences, Prof. D. Ackermann, of Würzburg, and Dr. F. Gademann, of Schweinfurt, did justice to the life-history and supra-national aims of the Leopoldina and of its foundation members-Brausch, Fehr, Metzger and Wohlfarth. These last-named were the first to put into practice the precepts, set out in the "New Atlantis" by Francis Bacon, for a scientific academy such as every principal city of Europe was soon to possess (London 1662, Paris 1666, Berlin 1711, Madrid 1713, St. Petersburg 1725, etc.). It is remarkable that this occurred in a small market-town, with a strong industrial background, in times of disruption rather like our own. A quotation that mystified some of the audience was from the curious charter that Kaiser Leopold I granted the Academy in 1687, when also it acquired its full name, conferring, as one of the normal privileges due to the Court rank bestowed on the president by the charter, the right to "legitimize illegitimate children" and to "declare dishonourable persons honourable".

Schweinfurt has preserved intact the fine library of more than a thousand volumes left to it by Dr. Bausch, chiefly on medical and botanical subjects; a large part was on view, together with works by other local Academy members-notably that on Japan ky Philipp Franz von Siebold (1832), and with it his "Life" by the Japanese, Prof. Shuzo Kuro (Tokyo, 1926), the largest biography of a European ever written by an Asiatic.

An impersonation of the native poet Friedrich Rückert (1788-1866), a Haydn serenade in the courtyard of Mainberg Castle and a visit to the exhibition of medieval Franconian church art at 
Würzburg Castle-the most striking feature of which was a large collection of the sculptures of Tilman Riemenschneider (1460-1531) - were the main social items in the proceedings, which were essentially informal. As in the case of the Halle celebrations, detailed reports will be published in the Nova Acta Leopoldina, including a full account of Prof. Gallwitz's researches. But, as yet, no copies of the current year's issue have reached the British bodies who were recipients before the War (and whose publications have been received up to date by the Academy), although at the time of the Halle meeting it was hoped to make up the deficiency forthwith.

R. C. H. Young

\section{FARM WATER SUPPLIES}

$\mathrm{O}$ October 21, under the auspices of the Society for Applied Bacteriology, a series of papers were read on various aspects of "Farm Water Supplies". The introductory paper was given by Mr. G. 'T. Morgan (Ministry of Agriculture and Fisheries), who at the outset emphasized the great importance of cleanliness in milk production and the significance of water supplies in this connexion. Of the 158,000 milk producers in Great Britain, 40 per cent own less than ten cows, and a large proportion still have inadequate and unsatisfactory water supplies to meet the estimated daily requirement of some 30-35 gallons per animal. With so many small units it is difficult to effect immediate improvements, particularly when so many of them have been producing satisfactory milk for many years. Information is being collected continuously, supplies are checked, and advice is given for improving their quality; reasonable time being allowed to correct faults and to effect the desired improvements.

Sir William Savage (Taunton), the eminent authority on public health matters, emphasized the need for a practical approach to the problem, since it is clear that piped supplies for all agricultural purposes are not possible, first on economic grounds and, secondly, because there is not sufficient water available. The quantities and qualities required must, therefore, be related to their uses. On only rare occasions have water supplies been incriminated in epidemics of bacterial infection, and in these cases the Salmonella and enteric organisms have been involved. Moreover, for most dairying purposes, the standards of water supplies need not be as high as those for general domestic supplies. Well and stream waters are quite satisfactory for animal drinking and for byre washing. Pure supplies are essential for washing all surfaces which come into direct contact with the milk. Sir William was sceptical of chemical disinfection, since this is usually carried out by unskilled farm hands.

Mr. W. A. Cuthbert (Leeds) said that 97 per cent of farm water supplies are from wells, usually shallow ones, or from springs. By means of a series of lantern slides he illustrated the unsatisfactory nature of many such wells and the difficulties of tracing the real sources of some of the springs. Infection in these waters are mainly found to be due to human pollution, which can be eliminated by appropriate protective measures, although these often involve reconstruction. Chlorination should also be employed, but this cannot be relied upon entirely to render a bad water safe. In farm water supplies, the counts of Bact. coli and coli-aerogenes groups vary independently, so that differentiation of fæcal and non-fæcal organisms is of little value for diagnostic purposes. Topographical examination of all supplies is essential and should be considered along with bacteriological findings before expressing judgment on any supply. Numerical standards for bacterial content are in themselves of no value in assessing farm water supplies because of the considerable seasonal variations encountered. Investigation has shown that factors responsible for this variation include soil temperature and, to a less extent, rainfall.

Dr. J. H. McCoy (Hull), considering the significance of polluted farm water supplies in relation to human infection, said that standard bacteriological tests cannot of themselves guaranteo the non-pathogenicity of any supply. Topographical examination is a first essential to eliminate obvious faults. Epidemics of milk-borne enteric infections are traceable mainly to carriers, but a small number is undoubtedly attributed to the water supply, for example, the Croydon epidemic of 1937. Dr. McCoy also directed attention to organisms likely to cause spoilage in dairy products, such as lipolytic and proteolytic bacteria in cheeses, but said that these should not be present in large numbers in properly handled milks. Mr. T. C. Ketchen (Ministry of Agriculture and Fisheries), again emphasizing the practical and financial aspects, described in detail several ways in which the design and maintenance of farm water systems could be improved. Examples were given of how these could be effected by fencing off springs and wells from animal contact, by substituting bore-holes for shallow wells, by re-directing and piping flows from springs, or by proper walling and fencing of well-mouths.

The discussion was opened by Dr. Windle Taylor, who emphasized the importance of chemical tests on waters, and expanded further the significance of the Bact. coli/coliform ratio, stating that fæcal Bact. coli appears to survive much longer in water than was originally thought.

\section{INTERNATIONAL SANITARY REGULATIONS}

$\mathrm{F}$

OR more than a hundred years the progressive nations of the world have endeavoured to arrange a uniform sanitary code to govern international traffic and to utilize the best preventive measures against the importation of infectious diseases, especially cholera, plague and yellow fever. Important work to this end was done by the PanAmerican Sanitary Bureau, the Office International d'Hygiène Publique, and the Health Organization of the League of Nations ${ }^{1}$. The development of air travel led to the International Sanitary Convention for Aerial Navigation, afterwards modified in 1944, like the convention of 1926 for maritime traffic.

During the first half of the present century there were as many as thirteen conventions or diplomatic arrangements relating to health control measures to be taken at frontiers. None of these conventions completely superseded all its predecessors, nor were all the States parties to these arrangements, some participating in certain of them and not in others. This disunity caused trouble and confusion in international traffic. Further defects were the delay in ratification, which prevented the application of the agreed measures rapidly and simultaneously; and 